\title{
Using Student-Created Content Videos in Flipped Learning to Enhance Student Higher- Order Thinking Skills, Engagement, and Satisfaction
}

\author{
Dr. Kodwo Annan \\ Georgia Gwinnett College \\ School of Science \& Technology \\ Lawrenceville, GA 30043, USA \\ Dr. Grace Onodipe \\ Dr. Andrew Stephenson \\ Georgia Gwinnett College \\ School of Business \\ Lawrenceville, GA 30043, USA
}

\begin{abstract}
Student-created content videos in flipped learning environment provides a new methodology for teaching and learning. This study examined effect of student-created content videos in statistics flipped classroom on students' higher-order thinking skills, engagement, and satisfaction. Explorative qualitative study was conducted using data from students' surveys and tests from integrated and non-integrated student-created video flipped classrooms to measure students' higher-order thinking skills, student engagement and satisfaction. Interviews and notes were conducted to support the data. A randomized controlled trial was implemented to examine the impact of student-created content videos on students' higher-order thinking skills, engagement and satisfaction. The findings revealed that flipped learning with student-created content videos is effective in increasing students' higher-order thinking skills, engagement, and satisfaction. The study posited that students who created their own content videos had more autonomous learning that satisfied their needs, freedom, and satisfaction. Also, those students were more engaged in their learning process and therefore became good and successful learners, consequently achieved high grades.
\end{abstract}

Keywords: Flipped Learning, Student-created videos, HOTS, Engagement, Satisfaction

\section{Introduction}

The learning process in the twenty-first century is undergoing a paradigm shift from teacher-centered learning into a student-centered learning with the characteristics of flipped learning (Bishop \& Verleger, 2013, O'Flaherty \& Phillips, 2015). Flipped learning is a pedagogical approach in which first encounter with new concepts moves from the group learning space to the individual learning space in the form of structured activity; and the resulting group space is transformed into a dynamic, interactive learning environment where the educator guides students as they apply concepts and engage creatively in the subject matter (Prodoehl, 2015).

In their white paper review of flipped learning, Hamdan, et al., (2013) introduced the first pillar of the FLIP learning as a Flexible Environment; where teachers provide a variety of learning modes, for example videos and podcasts, or group work and worksheets. The goal is to create a flexible learning culture where students can 'choose when and where they learn'. The second pillar is Learning Culture, meaning, the shift from a teacher-centered learning environment to one that is student-centered. This means that 'students move from being the product of teaching to the center of learning'. The third pillar is Intentional Content. This pillar emphasizes the importance in the design of both the information in the digital tools and the organization of the classroom activities. It is also about knowing what to 'flip' and what to deliver directly and matching the continual evaluation of delivery methods to the content. The last pillar, Professional Educator emphasizes the importance of having the support of the teacher present in class to guide students in their activities, hence supporting the fact that the flipped learning model does not neglect the importance of the competent educator's role in learning.

Based on these pillars, Bishop and Verleger, (2013) conducted the first known research review of the flipped classroom and defined flipped classroom as: '.. an education technique that consists of two parts: interactive group learning activities inside the classroom, and direct computer-based individual instruction outside the classroom.' (Bishop \& Verleger, 2013, p.3). Since then the flipped classroom has been understood as any approach where a teacher asks students to complete activities outside class, anything from reading, watching supplemental videos, or similar. 
However, flipped learning indicates something broader and more encompassing as defined by others (Flipped Learning Network (2014), Yarbro, et. al., 2014, p. 5).

While the term flipped classroom was used to indicate the collection of components that make up FLIP model, the video lectures and subsequent classroom activities, we will use the term flipped learning to indicate the overall Flip model and the theoretical teaching method. Both terms incorporate 'computer-based individual instruction' and 'a dynamic, interactive learning environment' under the direction of an educator. Either way, the focus on technology as the source for instruction as opposed to reading has become a clearer component of the flipped learning. According to Brooks (2014), flipped learning, entails using the affordances of digital technology to support teachers in creating virtual lessons. Thisis donein an effort to open up class time for interactive peer activities for the students to engage in while a teacher is present. Furthermore, Gough, et al., (2016) stated that making more class time available for various teaching activities can 'engage students with higher order thinking' and can enhance student satisfaction (Gross et al., 2015).

There are several technologies used for creating and implementing content materials for flipped learning where teachers and students can create, connect, and use these tools (Bates, 2015). Among these technological tools, video creation and interaction are the preferred toolsets by both teachers and students (Siemens, et al., 2015). Video is defined here as digitally recorded content that has sound and motion that can be stored, delivered live, or delayed, and can be streamed to a variety of devices. It may or may not have the lecturer visible and can be viewed on multiple (student owned) devices, in multiple formats, or platforms (before, during, and after class). Video usage currently dominates the internet and its increasing prevalence in daily life is reflected in the educational environment (Gough, et al., 2016). As the affordances and sharing capabilities of videos increase and become simplified, their viability and availability play a major role in facilitating teaching strategies within flipped learning (Bates, 2015). Creating videos for flipped learning require conscious effort to make the content meet the medium with multiple representations (Gough et al., 2016).

For the past decade, however, the production of video has gone from a small group of experts, to the general masses. It has become possible for anyone with a mobile phone to make a video recording. Mobile devices, from smartphones, digital devices, iPads, digital cameras, and 'video boxes' (which enable 'self-service video recording') have the standard option of recording video at an ever-increasing video quality and duration. Recorded video files can be uploaded instantly to social media and to institutional servers.

Beyond this, the new policy initiatives within education call for students, not only to be consulted during the development of learning strategies, but also become directly involved as co-designers, co-producers, and co-creators of their own learning (Könings et al. 2010, Bovill \& Bulley, 2011). The goal of these initiatives is to place student needs at the center of the design process and thus view the student as a knowledgeable and critical partner in his or her learning process. In other words, these initiatives are a change of mindset where students think about their learning and expect to take a more active role in creating the contents for their learning through technology (Bishop \& Verleger, 2013, Gough, et al., 2016).

While the idea of instructor-provided videos are already an established practice within flipped learning (Dudley et al., 2015), student-created videos (SCVs) are still rarely embraced in developing and constructing ideas of knowledge independently in flipped learning. The authors believe that students could be further engaged, more active in their learning, and improve their understanding of the content when they create their own videos of the content instead of instructor-created videos content. Therefore, the aim of this paper is to examine the impact of using student-created videos in flipped environment to measure student engagement and involvement, satisfaction, and whether they improved in their understanding of the materials they created the videos on. Specifically, our study will focus on whether there is some evidence that student-created content videos i) enhance student higher order thinking skills, (ii) impact student engagement and involvement, and iii) improve student satisfaction.

To investigate these enquiries, we provide brief literature review on student-created videos, student engagement, student satisfaction, and Higher-order Thinking Skills (HOTs), in the next section. The methodology which includes design, contextual setting, study participants, ethical considerations, and data collection is given in section 2 . Results and discussion are presented in section 3. Conclusion is given in section 4.

\section{Literature Review}

The innovation of student-generated course material using videos represents a novel way of teaching in flipped classrooms (Guertin, 2010; Bolliger et al., 2010; Kay, 2012). In general, this effort builds upon the use of student discussion activities in the class mode to enhance interaction and cognitive engagement. Student-created videos moves the interaction to a more thoughtful visual and auditory presentation of the content being studied. 
Referring to students as 'digital natives,' Skiba (2007) suggested that university classrooms must utilize photos, videos, and music to make classroom subject content appropriate to students' communication styles and learning. Besides, student created videos require even more preparation than a typical in-class presentation. Not only is it necessary for the student to synthesize various sources on the subject content, the student must also write it down as a script, read it, recite it and then create a video, sometimes requiring multiple "takes" and subsequent editing. Each of these steps repeatedly exposes and reinforces the materials for the student. Another important consequence to be expected of student-created video is that while students are actively engaged in the activity, they are actively learning, as compared to passively watching instructor created videos, and will enjoy the project and their fellow students. (Greene \& Crespi, 2012).

Research have documented student-generated video activities with no flipped learning settings primarily in the science and business disciplines. Surveys show different positive impacts (teamwork, communication, satisfaction) of podcasting in engineering (Alpay \& Gulati, 2010), information technology (Bolliger \& Armier, 2013), and nursing (Haraldseid, Friberg, \& Aase, 2016). Likewise, student responses indicated increased perceived learning (Alon and Herath, 2014). Moryl (2016) documented how student groups created their own YouTube videos of economic concept presentations and observed better engagement than the traditional flipped classroom. Other potential benefits of student-created videos in educational research literature included high level of student motivation (Kearney and Schuck, 2005), motivation and engagement (Fredenbery, 2008; Armstrong et.al. 2009). Specifically mentioned in these articles were notions such as: student empowerment - students developing capability to create multimedia presentations; students developing a sense of professionalism; students learning new people skills; students enjoying a nice break from the routine; students having a new and fun experience; and students developing a stronger appreciation for planning and team work.

Bloom's taxonomy is an instructional framework often used to determine the outcomes of teaching and learning (Bergmann \& Sams, 2014). The top three levels of Bloom's taxonomy (analyzing, evaluating and creating) are known as higher-order thinking skills (HOTS) while the bottom three (remembering, understanding and applying) are called the lower-order thinking skills (LOTS). When student-centered flipped learning is dominant, the Bloom's taxonomy is turned upside down. Students have to practice remembering, understating and applying at home through creating their own content videos which involves watching sample videos, visiting course-related websites, listening to audios or at least reading the lesson. Therefore, instructors spend valuable class time with students as they engage in activities that require upper-levels skills of Bloom's taxonomy, which facilitate deeper learning (Koch, 2016). Besides, HOTS encompass LOTS as well in addition to training students for real-world application outside the classroom since they involve a series of related problems that contain important facts to solve instead of just a series of related facts to memorize (Conklin, 2012). Thus, HOTS increase students' sense of control over ideas, so thinking is much more fun than memorizing.

Student satisfaction is the positive attitude toward the teaching and learning activities and experiences implemented in flipped learning. In traditional learning, the main reason for students' dissatisfaction is the instructor's dominance over the classroom which causes boring and passivity of students. Another reason is that students have the fear of committing mistakes inside the classroom which may prevent them from participation and questioning. The flipped classroom learning with student-created content videos may solve the dissatisfaction causes since it concentrates on the student-centered learning which makes learning enjoyable and meaningful. Farah (2014) examined the attitudes of students in a flipped technology class and observed that students' attitudes towards the flipped instruction was favorable. ALRowais (2014) also explored the impact of flipped learning on achievement and attitudes in higher education and concluded that there were positive effects of both the students' achievement and their attitudes towards studying courses. Moreover, Gross et al. (2015) also examined the effectiveness of the flipped classroom model on student engagement, student satisfaction, and academic performance. The finding revealed that high levels of student engagement and course satisfaction characterized the students in the flipped courses. Besides, Hung (2015) examined the possible impacts of flipping the classroom on students' academic performance, learning attitudes, and participation levels. The findings showed that flip lessons helped students to attain better learning outcomes, developed better attitudes toward their learning, and devoted more effort in the learning process. Thus, student satisfaction increased when using the flipped classroom learning. This study hopes to find higher level of student engagement and satisfaction when they creates their own content videos. 


\section{Experimental Setting}

\section{Participants \& Students Background}

This study took place in a 2000-level business statistics course at a 4-year open access public college in fall 2017. This course is required for all business majors and covers descriptive statistical measures all the way up to confidence intervals. Two sections of the course were taught by one of the authors as fully flipped classes, with students completing pre-class preparation assignments before coming to class and participating in peer instruction during class time with instructor guidance. Students indicated at the beginning of the semester that they had no prior experience with flipped learning. Sections 1 and 2 had 40 and 32 students respectively, and met twice a week for 75 minutes each session.

\section{Randomized Controlled Trial}

A randomized controlled trial (RCT) was implemented in both sections to examine the impact of student-created videos on students' HOTS, engagement and satisfaction. A total of seven chapters were covered in each class. Out of these seven chapters, four chapterswere selected for the RCT experiment (Wozny, Balser, \& Ives, 2018). As shown in Appendix A, Chapter 1 was taught as a traditional classroom with PowerPoint lectures, as students settled into the course during the first week of the semester. Chapter 2 was taught in flipped class format with instructor-created videos and student pre-class preparation. Students in section 1 were randomly assigned to Chapters 3 and 6 for StudentCreated Video assignments, while the remaining chapters 4, 5 and 7 were not required to create videos. Section 2 students were randomly assigned to Chapters 4 and 7, leaving chapters 3, 5 and 6 as flipped chapters without SCVs. It took two or three 75-minute class periods to adequately complete the content of each chapter in class before students were ready to record SCVs.

\section{Higher-Order Thinking Skills Tests}

The chapter tests were used to assess students thinking skills in analysis, evaluation, and creation. The test contents were analyzed according to the revised Bloom's taxonomy and only the higher-order thinking skills questions were chosen. Each test had 30 multiple choice questions, divided equally on three levels; analyzing (10 items), evaluating (10 items) and creating (10 items). Each question had four distracters (A, B, C, and D) and only one answer was correct for one point and zero for false answer. The creating questions required students to demonstrate their ability to create new ideas before arriving at the answer.

\section{The Flipped Classroom}

For the flipped classroom chapters, students were assigned short instructor-created instructional videos to watch before class. They also had a section of the textbook to read and PowerPoint Slides to review. While completing this pre-class work (PCW), they were required to take Cornell Notes to organize and summarize their understanding of the material. Specific requirements from the Cornell Notes included a section where they would write three questions that they did not understand from their readings. Those questions formed the basis for review at the start of class.

At the start of class, students took a short 4-question quiz on their mobile devices as a form of just-in-time-teaching (JiTT) and formative assessment to assess their understanding of the material and detect any systematic misconceptions and confusion. Results from this in-class quiz also form the basis for review. During the bulk of class time, students worked in peer groups to complete in-class activity handouts. These peer groups were made up of 2-4 students. While students worked in groups, the instructor moved around the classroom monitoring students' progress.

\section{Student-Created Video (SCVs)Assignments}

Students used Wacom Tablets and snowball microphones to record their videos in class and used Kaltura, which is embedded in Brightspace (formerly Desire-to-learn (D2L)) learning management system (LMS), for editing. Once the students record the videos, they publish them to the LMS. Students were trained on how to use the tablets and record before the project began. For each chapter, the instructor first prepared a number of short videos on some aspects of the contents and then tasked students to create and present their own videos at the end of the chapter on other aspects of the content. SCV handouts were given to each group at the beginning of the chapter with four problem sets which they needed to provide answers to in their recordings. A grading rubric (Appendix B) was also provided to the students with specifications about the length of the videos (not to exceed 4 minutes per video), concept correctness, quality of video, audience engagement, and professionalism. For each class period, time was allocated for the groups to work on their problems and one class period was devoted to video recording in class. Upon completion of the recordings, student videos were published on the LMS with instructions for students to watch the videos of their peers before the upcoming test. Students then discussed their involvement, perception and satisfaction of their learning process through questionnaires, interviews, and an end of semester survey. 


\section{Data Collection}

The data in the study were collected through chapter tests, notes taken by the instructor, group interviews, and surveys. Data collected from the tests were analyzed as follows: First, test averages were computed for each test for each section; then we examined the test grades by percentiles from weakest students to best students to see if there was any meaningful results; we then, broke down the test grades into SCV and no SCV to see if there was an impact of SCV assignments on students' thinking skills; t-test was used to compare the two sections average scores to see if there is any significant difference between mean scores on each test across sections.

Field notes were collected through informal meetings between the instructor and the students, during the delivery and return of the tablets, for instance, or if any students approached the instructor with comments about tablet use. All interviews were moderated by the instructor and interactions between the students were encouraged with the instructor asking, prompting, and clarifying questions. Interviews were not audio recorded, however, the instructor wrote notes to complement the interviews. Finally, surveys were conducted for the chapters that included SCVs.

Detailed measures on students' perception of the class, video creation, engagement, satisfaction, and involvement were measured through Likert-scale survey questions (Joosten \& Reddy, 2015). The survey comprised of twelve Likert scaled questions (rating $1=$ strongly disagree, $2=$ disagree, $3=$ neutral, $4=$ agree, $5=$ strongly agree) and three openended questions. The Likert scaled questions focused on student behavior and perceptions of creating their own videos on course content. Specifically, students were asked about their perceived course activity challenge, course interactivity, active learning behaviors and satisfaction, as well as their perceptions of the course social presence and engagement. Thus, a student choosing agree or strongly agree would be indicating more engagement and a higher perception of involvement and satisfaction in the class. The last three questions on the survey were open-ended queries regarding what students liked the most and least liked about creating their own videos for the class and whether their successes were impacted by the use of technology.

\section{Analysis and Results}

To investigate the impact of the SCVs on students' higher-order thinking skills, we present the SCV and no SCV test scores breakdown in Table 1 below. We observed that SCV mean scores were higher than non-SCV mean scores for sections 1 and 2 groups: $77.77 \%$ vs. $74.12 \%$ and $79.19 \%$ vs. $72.87 \%$, respectively. This may indicate that SCV group means were better than non-SCV group and so agreed with the hypothesis that using SCV in flipped learning is more effective in improving students' HOTS. Besides, the finding of this study was consistent with similar studies conducted between flipped and non-flipped classroom learning (Obari \& Lambacher, 2015; ALRowais, 2014).

Table 1: Descriptive Statistics for Higher-Order Thinking Skills Tests Scores

\begin{tabular}{lllllll}
\hline & & \# Grades & Mean & \multicolumn{2}{c}{ SD } & \multicolumn{2}{c}{ Confidence Interval } \\
\hline \multirow{2}{*}{ Section 1 } & SCV & 79 & $\mathbf{7 7 . 7 7}$ & 11.89 & 75.15 & 80.39 \\
\cline { 2 - 7 } & No SCV & 119 & $\mathbf{7 4 . 1 2}$ & 15.29 & 71.37 & 76.86 \\
\hline \multirow{2}{*}{ Section 2 } & SCV & 32 & $\mathbf{7 9 . 1 7}$ & 14.24 & 74.23 & 84.10 \\
\cline { 2 - 7 } & No SCV & 128 & $\mathbf{7 2 . 8 7}$ & 16.65 & 69.99 & 75.76 \\
\hline
\end{tabular}

This finding confirmed that SCVs in flipped learning is an effective model to enhance students' HOTS. The out of class video creation activities gave students the chance to review concepts and had a clear idea about the content before creating the videos. Likewise, students spent adequate time to learn the LOTS at their own pace and were able to write their comments and notes regarding the concepts. In classroom, the activities controlled by the instructor such as discussions, group work, etc. promoted student-centered and HOTS learning which improved content understandings.

To examine the impact of the SCVs on student engagement, the main items of analysis were the pre and post surveys. We first calculated scores for each Likert-scale question and then averaged the scores (between 1 and 5). The mean data obtained were computed using 2-sample mean t-test. The field notes and the interview were used as supplementary data material for the analysis. We observed a statistically significant difference between the mean scores of the pre $(\mathrm{M}=2.96, \mathrm{SD}=0.44)$ and post $(\mathrm{M}=4.11, \mathrm{SD}=0.46)$ surveys. The result indicated that using $\mathrm{SCV}$ s in flipped learning was effective in improving student engagement. In addition, $89.6 \%$ of students who participated in the video creation sessions of the study liked the idea of integrating video creations into the learning process. The findings suggested that SCVs in flipped learning were more engaging than a normal flipped learning activities and gave students greater opportunities to understand the concepts before creating the videos. Thus, students had to make sure they knew the materials well and understood what the concept was about before putting it on videos to be shown to their peers. 
In other words, it motivated students to learn the materials and encouraged them to use various illustrations/examples for students understanding. To observe the impact of the SCVs on student satisfaction, the student satisfaction exit survey (see Table 2) was analyzed. The overall mean score of student satisfaction was $(\mathrm{M}=4.15)$. All items were high, ranging from ( $\mathrm{M}=4.01$ to $\mathrm{M}=4.37)$, except a question on whether flipped learning with $\mathrm{SCV}$ s reduced time (M=3.86). Students were most satisfied with the SCVs flipped instruction which encouraged them to have creative thinking $(\mathrm{M}=4.37)$, the content and topics of the learning materials $(\mathrm{M}=4.22)$, the integration of technology and multimedia resources $(\mathrm{M}=4.21)$, the availability of suitable tools for supporting learning $(\mathrm{M}=4.25)$, the control and freedom of choosing what and how to learn $(M=4.17)$, and enjoying learning statistics via SCV creations $(M=4.26)$. These findings revealed that students in general were satisfied with the flipped instruction with SCVs and may indicate the importance of shifting from flipped learning to more effective SCVs flipped learning processes. Student satisfaction is imperative to learning statistics because statistics is not a spectator's course and having a meaningful learning experience needed more satisfied student.

\begin{tabular}{lll}
\hline \multicolumn{1}{c}{ Table 2: Student Satisfaction Questions (Number of Students = 72) } & Mean & SD \\
\hline The flipped learning with SCV helped me to learn the statistics materials. & 4.21 & 1.02 \\
\hline The flipped learning with SCV had tools for supporting my learning. & 4.25 & 0.75 \\
& & 0.71 \\
\hline The flipped learning with SCV encouraged me to have creative thinking. & 4.37 & 0.77 \\
\hline I am satisfied with the content and topics of the learning materials. & 4.22 & 0.77 \\
\hline I am satisfied with the format and structure of the learning materials. & 4.08 & 0.77 \\
\hline I am satisfied with the integration of technology and multimedia resources. & 4.21 & 0.68 \\
\hline I am satisfied with the control and freedom of choosing what and how to learn. & 4.17 & 0.90 \\
\hline The flipped learning with SCV gave control and dependency over my study. & 4.01 & 0.86 \\
\hline The use of the flipped learning with SCV was easy and applicable. & 4.14 & 0.68 \\
\hline The use of the flipped learning with SCV helped me to develop useful skills. & 4.04 & 1.13 \\
\hline The flipped learning with SCV reduced time required to learn. & 3.86 & 0.95 \\
\hline I enjoyed learning the statistics through the use of the flipped learning with SCV. & 4.26 & 0.81 \\
\hline
\end{tabular}

The findings demonstrated that student-created content videos in flipped learning increased student engagement and satisfaction and HOTS. Thus, when students are engaged and satisfied in the course, they may achieve high grades on HOTS.

Additionally, the open-ended questions were included in the analysis. Overall, most students commented on the video creation projects, engagement and learning aspects of the project, and confirmed the positive effects of peer learning. Students noted that they were more confident as a result of working in groups and also felt that learning from each other helped them to master the content and the video creation part of the projects. Students responses to the openended questions were grouped into: Content (meaning that they liked the SCV assignment because of how it helped them learn and understand the material better), Self-Esteem (referring to how creating videos made them feel a sense of accomplishment), Self-Expression (referring to how they were able to deliver content while showcasing their personalities), Technology (how they enjoyed using new/cool software), and Group Work (how they benefited greatly from working with classmates and getting different ideas and views from each other). Selected students' favorable responses include the following:

"That it was something different but enjoyable"

"I liked how it allowed us to express our own way of showing how to do certain concepts"

"What I liked most about the videos was that it was very interactive and it gave us a chance to have a little fun while also learning."

"What I liked the most about creating videos in this class was the process of creating them. This was my first time doing a video project so it gave me a new experience and I was able to learn the content for this class while doing it."

"It was very useful for practicing the information and making sure I knew the information well enough to explain it to others."

"What I liked the most was being able to actually work a problem out and feel good about the work I showed"

"It was fun and something outside the norm"

"It allowed us to showcase our work and explain how we were able to get a certain answer"

"The fact that you actually had to know the material before creating the video"

"The class video creation exercise changed my engagement in the class in a positive way it gave myself and other students accountability to interact by giving our personal feedback and explaining our problems."

"It helped me to better understand problems I couldn't solve on my own." 
"Creating my own content video was pretty helpful in increasing engagement within the class. It really made you learn the subject."

There were still a few negative comments, however, these negative comments could help design the project better in the future. Some students expressed discontent with the project because they were unfamiliar with the technology being used. Technology challenges mentioned as areas of improvement for future SCV projects included faster computers, different recording applications, and in-depth video creation tutorial. Perhaps, there are smoother ways for students to create the videos that would lessen the technical frustrations that were mentioned. However, these constructive responses are integral parts of professional learning and allow instructors to see how they could improve and also provide suggestions for others who intend to embark on similar projects. Judging from the students comments, we feel that the video creation of the content in flipped learning was a successful endeavor that needs to be enhanced to provide a smoother learning experience for students.

\section{Conclusion}

Student-created content videos in flipped learning environment provided a new methodology for teaching and learning that empowered students to take ownership of their learning and enjoy the process. In this research, we examined how student-created content videos may enhance students' higher-order thinking skills, engagement, and satisfaction. The findings revealed that flipped learning with student-created content videos is effective in increasing students' higherorder thinking skills, engagement, and satisfaction. The study confirmed that students prefer to be in the center of their learning by creating their own content videos to use and to share with their peers. In this way, they have more autonomous learning that satisfied their needs. Student satisfaction was very important because it pushed them to engage and have a meaningful learning experience. Also, when students are engaged and satisfied in their learning process, they become good and successful learners and thus achieve high grades. In addition, students saw the process of creating the videos as entertaining and educational and gave them the opportunity to connect with fellow students. Furthermore, while the benefits of students-created content videos were highlighted positively in the students' comments, technology use was less positive. Further preparation is needed to improve technological use of video devices in future similar projects.

\section{References}

Alon, I., \& Herath, R. (2014). Teaching international business via social media projects. Journal of Teaching in International Business, 25, 44-59.

Alpay, E., \& Gulati, S. (2010). Student-led podcasting for engineering education. European Journal of Engineering Education, 35, 415-427.

ALRowais, A. (2014). The Impact of Flipped Learning on Achievement and Attitudes In Higher Education. International Journal for Cross-Disciplinary Subjects in Education (IJCDSE), Special Issue, 14(1), 1914-1921.

Armstrong, G., Tucker, J., \& Massad, V. (2009). Achieving learning goals with student-created podcasts. Decision Sciences Journal of Innovative Education, 7, 149-154.

Bates, A. W. (2015). Teaching in a digital age; Guidelines for designing teaching and learning for a digital age. open.bccampus.ca. Retrieved from http://opentextbc.ca/teachinginadigitalage/

Bergmann, J. \&Sams, A. (2014). Flipped Learning: Gateway to Student Engagement. Washington DC: International Society for Technology in Educatio

Bishop, J., Dr. Verleger, M. (2013). The Flipped Classroom: A Survey of the Research. American Society for Engineering Education. June 23-26, 2013.

Bolliger, D., \& Armier, D., Jr. (2013). Active learning in the online environment: The integration of student-generated audio files. Active Learning in Higher Education, 14, 201-211.

Bolliger, D., Supanakorn, S., \& Boggs, C. (2010). Impact of podcasting on student motivation in the online learning environment. Computers and Education, 55, 714-722.

Bovill C, Bulley CJ. A model of active student participation in curriculum design: Exploring Desirability and Possibility. In: Rust C, editor. Improving Student Learning (ISL) 18: Global theories and Local Practices: Institutional, Diciplinary and Cultural Variations. Oxford: Oxford Brookes University; 2011.

Brooks, Andrea Wilcox. Information Literacy and the Flipped Classroom: Examining the Impact of a One-Shot Flipped Class on Students Learning and Perceptions. Communications in Information Literacy. 8(2): 225-235. (2014).

Burn, A., Brindley, S., Durran, J., Kelsall, C., Sweetlove, J., \& Tuohey, C. (2001). The rush of images: A research report into digital editing and the moving image. English in Education, 35(2), 3447.

Conklin, W. (2012). Higher-Order Thinking Skills to Develop 21st Century Learners. Huntington Beach: Shell Education 
Dudley L, Gamble C, Preston J, Buck D, Hanley B, Williamson P, et al. What Difference Does Patient and Public Involvement Make and What Are Its Pathways to Impact? Qualitative Study of Patients and Researchers from a Cohort of Randomised Clinical Trials. PloS one. 2015; 10(6).

Farah, M. (2014). The Impact of Using a Flipped Classroom Instruction on the Writing Performance of Twelfth Grade Female Emirati Students in the Applied Technology High School (ATHS). Master thesis. The British University, Dubai.

Fredenberg, M. (2008). Principles and Pedagogy, The two Ps of podcasting in the information technology classroom, Information Systems Education Journal, 6(6), pgs 111.

Gehringer, E. F. \& Miller, C. S. (2009, March). Student-generated active-learning exercises. SIGCSE (Computer Science Education) Bulletin 41(1), 8185. doi=10.1145/1539024.1508897 Retrieved from http://doi.acm.org/10.1145/1539024.1508897.

Gough, E., DeJong, D., Grundmeyer, T., Baron, M., K-12 Teacher Perceptions Regarding the Flipped Classroom Model for Teaching and Learning. Journal of Educational Technology Systems 2017, Vol. 45(3), p. 390-423.

Greene, H., \& Crespi, C. (2012). The value of student created videos in the college classroom-an exploratory study in marketing and accounting. International Journal of Arts and Sciences, 5(1), 273-283.

Gross, B., Marinari, M., Hoffman, M., DeSimone, K. \& Burke, P. (2015). Flipped @ SBU: Student Satisfaction and the College Classroom. Educational Research Quarterly, 39(2), 36-52.

Guertin, L. (2010). Creating and using podcasts across the disciplines. Currents in Teaching and Learning, 2, 4-12.

Hamdan, N., Arfstrom, K., McKnight, P., \& McKnight, K., (2013). A review of flipped learning. Retrieved from http://www.flippedlearning.org/review

Haraldseid, C., Friberg, F., \& Aase, K. (2016). How can students contribute? A qualitative study of active student involvement in development of technology learning material for clinical training. BMC Nursing, 15:2.

Hoffenberg, H., \& Handler, M. (2001). Digital video goes to school. Learning and Leading with Technology, 29(2), 1015.

Hung, H. (2015). Flipping the classroom for English language learners to foster active learning. Computer Assisted Language Learning, 28(1), 81-96.http://dx.doi.org/10.1080/09588221.2014.967701

Joosten, T., \& Reddy, D. (2015, October 1). Distance education and technological advancements research toolkit. National Research Center for Distance Education and Technological Advancements (DETA). Retrieved from http://uwm.edu/deta/toolkits/

Kay, R. (2012). Exploring the use of video podcasts in education: A comprehensive review of the literature. Computers in Human Behavior, 28, 820-831.

Kearney, M. \& Schuck, S. (2005). Students in the director's seat: Teaching and learning with student-generated video. In P. Kommers \& G. Richards (Eds.), Proceedings of the 2005 World Conference on Educational Multimedia, Hypermedia and Telecommunications (pp. 2864-2871).

Koch, J.(2016). Teach3: Introduction to education. Boston, MA: Cengage Learning

Könings KD, Brand-Gruwel S, van Merriënboer JJG. An approach to participatory instructional design in secondary education: an exploratory study. Educ Res. 2010;52(1):45-59.

Moryl, R. (2013). T-shirts, moonshine, and autopsies: Using podcasts to engage undergraduate microeconomics students. International Review of Economics Education, 13, 67-74.

Moryl, R. (2016). Pod learning: Student groups create podcasts to achieve economics learning goals. The Journal of Economic Education, 47, 64-70.

New, J. (2006). Film school: The silver screen inspires young minds to think big. Edutopia, 1(9), 2023. Retrieved from: http://www.edutopia.org/film-school.

O'Flaherty, J., \& Phillips, C., (2015). The use of flipped classrooms in higher education: A scoping review. The Internet and Higher Education. February, 2015. 25, p. 85-95.

Parker, D. (2002). Show us a story: An overview of recent research and resource development work at the British Film Institute. English in Education, 36(1), 3844.

Prodoehl, D. (2015). Flipping First-Year English: Strengthening Teacher-Student Conferencing through Online Modules. In A. Abigail (Eds.), Implementation and Critical Assessment of the Flipped Classroom Experience (1-24). Hershey: Information Science Reference.

Ryan, S. (2002). Digital video: Using technology to improve learner motivation. Modern English Teacher, 11(2), 7275.

Schuck, S. \& Kearney, M. (2004). Students in the director's seat: Teaching and learning across the school curriculum with student-generated video (Research Report). Retrieved from University of Technology, Sydney, Teacher Learning and Development Research Group website: http://epress.lib.uts.edu.au/research/bitstream/handle/10453/14209/SchuckKearney.04.pdf?sequence=1. 
Siemens, G., Gašević, D., \& Dawson, S. (2015). Preparing for the digital university: a review of the history and current state of distance, blended, and online learning. Athabasca: Athabasca University. Retrieved from http://linkresearchlab.org/PreparingDigitalUniversity.pdf

Skiba, D. (2007, March/April). Nursing education 2.0 YouTube, Nursing Education Perspectives, 28(2) 100-102.

Wozny, N., Balser, C., \& Ives, D. (2018). Evaluating the flipped classroom: A randomized controlled trial. The Journal of Economic Education, 49(2), 115-129.

Yarbro, J., Arfstrom, K., McKnight, K., McKnight, P., (2014). Extension of a review of Flipped Learning. Creative Commons Attribution. June, 2014.

\section{Appendix A: Course Schedule}

\begin{tabular}{|l|l|l|l|}
\hline Chapter & Topic & Section 1 & Section 2 \\
\hline Chapter 1 & Data and Statistics & Traditional Lecture & Traditional Lecture \\
\hline Chapter 2a & Categorical Variable summaries & Flipped Class & Flipped Class \\
\hline Chapter 2b & Quantitative Variable summaries & Flipped Class & Flipped Class \\
\hline & Test \#1 & & \\
\hline Chapter 3a & Measures of Location & Flipped Class with SCV & Flipped Class \\
\hline Chapter 3b & Measures of Variability & Flipped Class with SCV & Flipped Class \\
\hline Chapter 3c & Measures of Distribution Shape & & \\
\hline & Test \#2 & Flipped Classroom & Flipped Classroom w/ SCV \\
\hline Chapter 4a & $\begin{array}{l}\text { Counting Rules \& Assigning } \\
\text { Probabilities }\end{array}$ & Flipped Classroom & Flipped Classroom w/SCV \\
\hline Chapter 4b & Events and their Probabilities & Flipped Classroom & Flipped Classroom w/SCV \\
\hline Chapter 4c & Basic Probability Relationships & Flipped Class & \\
\hline & Test \#3 & Flipped Class \\
\hline Chapter 5a & Random Variables & Flipped Class & Flipped Class \\
\hline Chapter 5b & Binomial Probability Distributions & & Flipped Class \\
\hline Chapter 5c & Poisson Probability Distributions & Flipped Class with SCV & Flipped Class \\
\hline & Test \#4 & Flipped Class with SCV & Flipped Class \\
\hline Chapter 6a & Uniform Probability Distribution & Flipped Class \\
\hline Chapter 6b & Normal Probability Distribution & & \\
\hline Chapter 6c & Exponential Probability Distribution & Flipped Class with SCV & Flipped Classroom w/SCV \\
\hline & Test \#5 & Flipped Classroom & Flipped Classroom w/SCV \\
\hline Chapter 7a & Selecting a Sample & Flipped Classroom & Flipped Classroom w/SCV \\
\hline Chapter 7b & $\begin{array}{l}\text { Point Estimation \& Sampling } \\
\text { Distribution }\end{array}$ & Flipped Classroom & \\
\hline Chapter 7c & Sampling Distribution of $\bar{x}$ & & \\
\hline & Cumulative Final Exam & & \\
\hline
\end{tabular}

\section{Appendix B: Surveys}

\begin{tabular}{|l|l|l|l|l|l|}
\hline & $\begin{array}{l}\text { Strongly } \\
\text { Disagree }\end{array}$ & Disagree & Neutral & $\begin{array}{l}\text { gree } \\
\text { Strongly } \\
\text { Agree }\end{array}$ \\
\hline STUDENT ENGAGEMENT QUESTIONNAIRE & $\mathbf{1}$ & $\mathbf{2}$ & $\mathbf{3}$ & $\mathbf{4}$ & $\mathbf{5}$ \\
\hline $\begin{array}{l}\text { The flipped classroom with SCV was more engaging than flipped } \\
\text { classroom instruction. }\end{array}$ & $\square$ & $\square$ & $\square$ & $\square$ & $\square$ \\
\hline $\begin{array}{l}\text { The flipped classroom with SCV gave me greater opportunities to } \\
\text { learn with other students. }\end{array}$ & $\square$ & $\square$ & $\square$ & $\square$ & $\square$ \\
\hline $\begin{array}{l}\text { I felt that flipped learning with SCV has improved my } \\
\text { understanding. }\end{array}$ & $\square$ & $\square$ & $\square$ & $\square$ & $\square$ \\
\hline I was more motivated to learn statistics in SCV-flipped classroom. & $\square$ & $\square$ & $\square$ & $\square$ & $\square$ \\
\hline
\end{tabular}




\begin{tabular}{|l|l|l|l|l|l|}
\hline When we worked on SCV projects, I felt encouraged. & $\square$ & $\square$ & $\square$ & $\square$ & $\square$ \\
\hline I asked myself questions to make sure I understood the material. & $\square$ & $\square$ & $\square$ & $\square$ & $\square$ \\
\hline Before I started a project, I planned how I was going to do it. & $\square$ & $\square$ & $\square$ & $\square$ & $\square$ \\
\hline I enjoyed discussing concepts with my peers. & $\square$ & $\square$ & $\square$ & $\square$ & $\square$ \\
\hline The class made me want to learn more about the material. & $\square$ & $\square$ & $\square$ & $\square$ & $\square$ \\
\hline In the class, I did more than required. & $\square$ & $\square$ & $\square$ & $\square$ & $\square$ \\
\hline
\end{tabular}

\begin{tabular}{|l|l|l|l|l|l|}
\hline & $\begin{array}{l}\text { Strongly } \\
\text { Disagree }\end{array}$ & Disagree & Neutral & gree & $\begin{array}{c}\text { Strongly } \\
\text { Agree }\end{array}$ \\
\hline STUDENT SATISFACTION QUESTIONNAIRE & $\mathbf{1}$ & $\mathbf{2}$ & $\mathbf{3}$ & $\mathbf{4}$ & $\mathbf{5}$ \\
\hline $\begin{array}{l}\text { The flipped learning with SCV helped me to learn the statistics } \\
\text { materials. }\end{array}$ & $\square$ & $\square$ & $\square$ & $\square$ & $\square$ \\
\hline $\begin{array}{l}\text { The flipped learning with SCV had tools for supporting my } \\
\text { learning. }\end{array}$ & $\square$ & $\square$ & $\square$ & $\square$ & $\square$ \\
\hline $\begin{array}{l}\text { The flipped learning with SCV encouraged me to have creative } \\
\text { thinking. }\end{array}$ & $\square$ & $\square$ & $\square$ & $\square$ & $\square$ \\
\hline I am satisfied with the content and topics of the learning materials. & $\square$ & $\square$ & $\square$ & $\square$ & $\square$ \\
\hline $\begin{array}{l}\text { I am satisfied with the format and structure of the learning } \\
\text { materials. }\end{array}$ & $\square$ & $\square$ & $\square$ & $\square$ & $\square$ \\
\hline $\begin{array}{l}\text { I am satisfied with the integration of technology and multimedia } \\
\text { resources. }\end{array}$ & $\square$ & $\square$ & $\square$ & $\square$ & $\square$ \\
\hline $\begin{array}{l}\text { I am satisfied with the control and freedom of choosing what and } \\
\text { how to learn. }\end{array}$ & $\square$ & $\square$ & $\square$ & $\square$ & $\square$ \\
\hline $\begin{array}{l}\text { The flipped learning with SCV gave control and dependency over } \\
\text { my study. }\end{array}$ & $\square$ & $\square$ & $\square$ & $\square$ & $\square$ \\
\hline The use of the flipped learning with SCV was easy and applicable. & $\square$ & $\square$ & $\square$ & $\square$ & $\square$ \\
\hline $\begin{array}{l}\text { The use of the flipped learning with SCV helped me to develop } \\
\text { useful skills. }\end{array}$ & $\square$ & $\square$ & $\square$ & $\square$ & $\square$ \\
\hline The flipped learning with SCV reduced time required to learn. & $\square$ & $\square$ & $\square$ & $\square$ & $\square$ \\
\hline $\begin{array}{l}\text { I enjoyed learning the statistics through the use of the flipped } \\
\text { learning with SCV. }\end{array}$ & $\square$ & $\square$ & $\square$ & $\square$ & $\square$ \\
\hline
\end{tabular}

\begin{tabular}{|l|l|l|l|l|l|}
\hline & $\begin{array}{l}\text { Strongly } \\
\text { Disagree }\end{array}$ & Disagree & Neutral & $\begin{array}{l}\text { gree } \\
\text { Atrongly } \\
\text { Agree }\end{array}$ \\
\hline STUDENT CREATED VIDEO EXPERIENCE & $\mathbf{1}$ & $\mathbf{2}$ & $\mathbf{3}$ & $\mathbf{4}$ & $\mathbf{5}$ \\
\hline Creating videos is an Important Exercise & $\square$ & $\square$ & $\square$ & $\square$ & $\square$ \\
\hline Creating videos is an Enjoyable Experience & $\square$ & $\square$ & $\square$ & $\square$ & $\square$ \\
\hline Creating videos is a Useful Experience & $\square$ & $\square$ & $\square$ & $\square$ & $\square$ \\
\hline Creating videos is an Interesting Experience & $\square$ & $\square$ & $\square$ & $\square$ & $\square$ \\
\hline I am Glad I created a video & $\square$ & $\square$ & $\square$ & $\square$ & $\square$ \\
\hline Participating in the video project will Help My Career & $\square$ & $\square$ & $\square$ & $\square$ & $\square$ \\
\hline Creating videos Enhances Learning Content & $\square$ & $\square$ & $\square$ & $\square$ & $\square$ \\
\hline Creating videos will Enhance Learning in Future classes & $\square$ & $\square$ & $\square$ & $\square$ & $\square$ \\
\hline I would Recommend This Project for future classes & $\square$ & $\square$ & $\square$ & $\square$ & $\square$ \\
\hline I found my classmates videos useful when I watched them & $\square$ & $\square$ & $\square$ & $\square$ & $\square$ \\
\hline
\end{tabular}

1. What do you like the most about creating videos for this class?

2. What do you like the least about creating videos for this class?

3. What could your professor have done to make the technology/teaching approach better? 